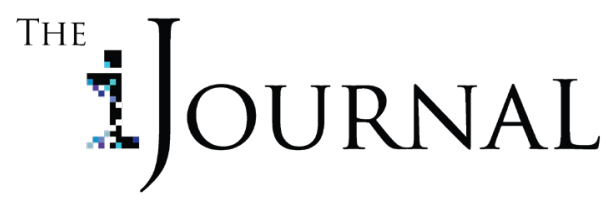

Bondi, C. (2019). The ijournal 5, I, I07-

|24. 10.33|37/ijournal.v5il.3347|

\title{
Doors Open, Doors Closed: Toronto's Little Free Libraries
}

\section{Christina Bondi}

\section{Abstract}

This paper explores the Little Free Library via the probes of library-variant and infrastructural experience. A fruitful discussion on the benefits and drawbacks will maintain the concept's contentious nature. The research even sheds light on the socio-economic politics embedded in Little Free Libraries and how they engage with race and class in a curious way. I also include some fieldwork, to supplement the paper's key arguments. In particular, I selected a sampling of three Little Free Library sites, closest to the University of Toronto campus: two in the Annex (on Prince Arthur Ave. and Brunswick Ave.) and one in Koreatown (on Euclid Ave.). The visual characteristics and location/placement of these miniature libraries have been taken into account. I interviewed a couple informants, each connected in some way to one of the Little Free Libraries from my sampling. The paper then concludes by proposing valuable avenues for future, collaborative research. 


\section{The Little Free Library: Setting the Scene}

Every Saturday morning, Emily and her daughter Mia visit their neighbourhood's Little Free Library. The structure stands in front of Abbie's house-an elderly lady who also serves as steward. Abbie has made note of Emily and Mia's Saturday morning visits; she is present and engages with them. All together, they investigate the small, vibrantly painted Little Free Library and discover new children's books.

The above constructed anecdote offers an archetypal (idealized) model for the Little Free Library concept. Little Free Libraries are often described as 'a 'take a book, return a book' free book exchange" ("Little Free Library FAQs," n.d.). Todd Bol, from Wisconsin, first set the scene by constructing one of these structures in 2009, prompting much intrigue ("The History of Little Free Library," n.d.). A year later, he put an official organization in motion for such Little Library creations, whose energy—in popularity and diffusion—persists today ("History of Little Free Library," n.d.). Quite recently, the Little Free Library "surpassed 90,000 registered Libraries in more than 90 countries worldwide" ("History of Little Free Library," n.d.). In the following essay, I begin with a brief fieldwork expedition, which involves the observation and reflection of three selected Toronto Little Free Libraries. With this in mind, I then deconstruct these structures as 'variants' of more conventional libraries-comparable in some respects but divergent in others. Furthermore, the Little Free Library as an infrastructure will be examined in-depth. I will put an ample collection of perspectives into a meaningful dialogue, so as to map out both the advantages and disadvantages of the Little Free Library. This examination will shed light on the socio-economic politics embedded in Little Free Libraries. It will reveal how the location of these libraries engage with race and class in a curious way. My collection of literature includes both academic and mass media perspectives, complete with books, scholarly journals, and news articles/blogs. Throughout the course of this essay, I aim to probe and argue for the value of two Little Free Library dimensions: as library-variant and infrastructural experience.

\section{A Little Free Library Expedition}

A short time ago, I set out on a brief 'in-the-field' expedition to explore and document (via written notes and photography) Toronto's Little Free Libraries. In order to effectively narrow down my search, I first visited the Little Free Library webpage map ("Little Free Library World Map," n.d.). The embedded Google Maps feature allowed me to input my location (Toronto, 
Ontario) and identify Little Free Library sites within the city. I then selected a sampling of three sites, closest to the University of Toronto campus: Charter \#21069 (Duke of York) on Prince Arthur Ave., Charter \#33975 on Brunswick Ave., and Charter \#26256 on Euclid Ave. ("Little Free Library Map," n.d.). The reasoning behind this selection was two-fold. I was specifically interested in delving into the Little Free Libraries of Toronto '(purposive' sampling). Yet, I still preferred the three libraries within walking distance of the university campus - a 'convenience' sampling. It is essential to note that these Little Free Libraries are a small sampling: my findings are preliminary and not wholly representative of Toronto. Nonetheless, the following fieldwork exercise provided a valuable point of entry into probing Toronto's Little Free Libraries.

Of my selected sampling, the first Little Library site was located just outside the entrance of a pub called Duke of York-part of Toronto's Annex neighbourhood, but still near Yorkville ("Little Free Library Map," n.d.). The pub is on a side street (Prince Arthur Ave.) parallel to Bloor St. West. ${ }^{1}$ I first noticed that this particular Little Free Library's colour palette-black, yellow, and grey-corresponded with the pub's logo and exterior features. The structure itself employed wood (core container and shelves), glass (panel on the front 'door'), and a metal latch on the right side (to unlock and open/close the door). On the day of my visit, I noted that its four shelves included predominantly fiction, history, biography, and cookbooks (see Appendices A to C).

The second Little Free Library is within a residential pocket (Brunswick Ave.), also part of the Annex. The structure appeared in front of a delightful, yellow semi-detached house with a blue door, which may have been the inspiration for its colour palate. While the Duke of York's was fastened to the wall, this particular Library was mounted onto a wooden post. It also included a distinct roof of wooden shingles. The painted imagery was quite peculiar-with retroesque robots, a space shuttle, and vegetation. On the day of my visit, I noted that its two shelves included, but were not limited to, adult and children fiction (predominantly), lifestyle/how-to books (e.g. gardening), and a comic book (see Appendices D to F).

The last Little Free Library of my brief expedition brought me to Koreatown (Euclid Ave.). Like the second, this structure existed before a semi-detached house in a residential neighbourhood. It also featured wooden shingles and a mounting-post, though the structure seemed a bit unsteady. The Little Library had been painted blue, white, and brown, and included a double-door with metal knobs. I noted much fiction, but also a couple female psychology/ wellness books and a first-aid guide (see Appendices G to I). 
All three Little Free Libraries comprised of a glass front panel so as to presumably display their books to passersby. They were also quite full, which could mean that people do use the Little Libraries often. ${ }^{2}$ They also included an official logo with a charter number; this signifies that these Little Free Libraries are registered in, and therefore legitimized by, the Little Free Libraries organization (“Start Your Own Little Free Library," n.d.).

\section{Little Free Library as Library-Variant}

In The Library Beyond the Book, Schnapp and Battles consider the four valuable dimensions of a library's space and contents: connection, storage, activation, and architectonics (2014, pp. 17-32). The authors describe 'connection' as techniques, tools, and metadata (e.g. catalogues and labels) that allow librarians and patrons to create an intermingling of books, where one book can be associated with another (Schnapp \& Battles, 2014, pp. 17-19). The Little Free Library moves away from many of the traditional library's methods of connection listed above. The primary connection between Little Library books is that they dwell together in a miniature containment (“About Little Free Library," n.d.; "Little Free Library FAQs," n.d.; "History of Little Free Library," n.d.). Catalogues or labels would be unnecessary and unsuitable for the Little Free Library format, since new books are added quite often, and some may never return (“About Little Free Library," n.d.; "Little Free Library FAQs," n.d.; Schnapp \& Battles, 2014, pp. 17-19; "History of Little Free Library," n.d.). The only established and practical tool is that one can search for a nearby Little Free Library via the website's map ("Little Free Library Map," n.d.). In addition, these books remain anonymous until a passerby opens the Little Library and explores the selection. They may or may not be linked by genre, since community members need only drop off any book of their choice when they take one ("About Little Free Library," n.d.; "Little Free Library FAQs," n.d.; Schnapp \& Battles, 2014, pp. 17-19; "History of Little Free Library," n.d.). Facilitators of Little Free Libraries present them as holding one-of-a-kind "literary treasures" or "gift-sharing" units, in which books live cooperatively in one area (Aldrich, 2014; "History of Little Free Library," n.d.). Of course, Little Libraries are promoted as tools for drawing in members of the neighbourhood or community ("About Little Free Library," n.d.; Aldrich, 2015, Aldrich, 2014; Cottrell, 2018; Guarino, 2015; Kozak, 2017; Smith \& Foster, 2012, Ulin, 2015). I will return to this idea in the section.

With regards to the 'storage' dimension, Little Free Libraries are also "more than mere 
storage-houses where documents are kept" (Schnapp \& Battles, 2014, p. 19). Passersby can engage with the voices of authors and neighbours (Aldrich, 2015; Aldrich, 2014; Cottrell, 2018, Guarino, 2015; Schnapp \& Battles, 2014, p. 19; Ulin, 2015). An article in The Atlantic corresponds with this line-of-thought by asking "Who left the Brazilian travel guides, and who's reading Camus?... And where will my copy of The Odyssey end up when I leave it in the library for someone else?" (Aldrich, 2014). Even in a digital age, these Little Libraries still attempt to hold onto a "collective imagination" (Schnapp \& Battles, 2014, p. 19) of the traditional library, which offers a physical space for tangible books - versus the pressures of e-changes (Mattern, 2012; Schnapp \& Battles, 2014, pp. 19-21). Though often considered “low-tech" (Aldrich, 2015) or "anti-tech" (Aldrich, 2014), Little Free Libraries still rely heavily on social media platforms to spread their message with others (Aldrich, 2015; Schmidt \& Hale, 2017, p. 31). For example, the organization has a website (with a blog), newsletter, and select social media (e.g. Facebook, Instagram, Twitter, Pinterest) accounts (Aldrich, 2015; "Homepage," n.d., Schmidt \& Hale, 2017, p. 31).

However, like the internet, Little Free Libraries provide around-the-clock service ("About Little Free Library," n.d.; "Little Free Library FAQs," n.d.);one can select a book at 3 AM or 5 PM. In other words, their dimension of 'activation' is unresting, unless the structure has been damaged (“About Little Free Library," n.d.; "Little Free Library FAQs," n.d.; Schnapp \& Battles, 2014, p. 21; Megan, "Who Would Vandalize a Little Free Library?," 2016). Little Free Libraries bring to life 'threshold realms' within the neighbourhood-or "zone of semi-private space" (Webster, Gollner, \& Nathan, 2015). In my brief expedition, two structures were placed in the front-yards of houses yet were still close to the public street. The Duke of York's Little Free Library was the closest to a larger building (on the front-porch); even still, pubs are public leisure spaces (Webster, Gollner, \& Nathan, 2015). Schnapp and Battles (2014) admit that, curiously, "library visits and usage statistics in the information age, rather than contracting, have grown" (p. 21). They describe individuals or groups who believe that the library is superior to the Internet, as the latter "is unevenly distributed and nowhere a given" (Schnapp \& Battles, 2014, p. 21). Similarly, Little Free Libraries argue for spaces of elevated openness and receptiveness (“About Little Free Library," n.d.; Aldrich, 2014; Cottrell, 2018; Smith \& Foster, 2012). Yet, as I will make note of in the subsequent section, this may not always be the case-we must "examine the situations of those who [in Toronto] are not served by" (Star, 1999, p. 380) Little Free Libraries.

Once they proceed to a discussion of 'architectonics', Schnapp and Battles (2014) pose the question, "techa: a case for what?" (p. 26). Soon after, the authors define the library (as 
containment) in the form of a "microcosm" (Schnapp \& Battles, 2014, p. 26). Comparatively, Little Free Libraries can be seen and understood in the same light; in a scaled-down form, they embody crucial fragments of personalities, experiences, and stories of people within and even beyond the neighbourhood (Aldrich, 2015; Aldrich, 2014; Cottrell, 2018, Guarino, 2015; Mattern, 2012; Schnapp \& Battles, 2014, pp. 26-27; Ulin, 2015). Furthermore, Little Free Library structures play with the binary of inside versus outside: they do house and protect the books within but at the same time, have also been completely integrated into the street/block and neighbourhood (Schnapp \& Battles, 2014, p. 27). Passersby cannot physically enter into the Little Library, and they will hear the vibrant sounds of outdoor surroundings as they explore the literature (Schnapp \& Battles, 2014, p. 27). The books give each Little Free Library distinctive identities and meanings (Mattern, 2012; Schnapp \& Battles, 2014, p. 29). Even still, there is something pure and honourable about these structures (alike a more traditional library space), as people have reacted negatively and even voiced their distaste for those who steal (e.g. large quantities of books) from or vandalize Little Free Libraries (Mattern, 2012; Schnapp \& Battles, 2014, p. 29; Megan, “Who Would Vandalize a Little Free Library?," 2016).

Because "knowledge is perpetually in motion" (Edwards et al., 2013, p. 6), these Little Library structures continuously embrace dynamism ("About Little Free Library," n.d.; Aldrich, 2014; "Little Free Library FAQs," n.d.; "History of Little Free Library," n.d.; Schnapp \& Battles, 2014, p. 29). Beyond simply acquiring books, Little Free Libraries also stress giving back, in the form of one of your own books ("About Little Free Library," n.d.; Aldrich, 2014; "Little Free Library FAQs," n.d.; "History of Little Free Library," n.d.). At the time of my study, the General Manager of the Duke of York shared that " $[\mathrm{w}]$ hile we have a great love for the traditional library, this informal format certainly suits us much better. People are free to come and go, they can stop into the pub with a new find and start reading right away, or they can spot a gem on the way out and take it home to enjoy without needing a library card!" (Jay Ashmore, personal communication, April 4, 2018).

Little Free Libraries can be linked to "itinerant libraries and mobile book delivery services" (Schnapp \& Battles, 2014, p. 98), in that books will move from one house to another via the medium of such a structure. Even so, while the content will experience constant flux, the Little Free Library enclosures/containments stay fixed in one place. The steward of the Euclid Ave. Little Library revealed the following: "I am a big supporter of wheel libraries and this [his Little Library] is just another complimentary system that will allow people to read more" (Ryan Penn, personal communication, April 3, 2018). The Little Free Library also serves as an example of the "momentary librar[y]" (Schnapp \& Battles, 2014, p. 116). That is to say, the 
books "mak[e] a virtue of impermanence" (Schnapp \& Battles, 2014, p. 115)—and they may be there one hour and (potentially) gone or replaced the next. One person must therefore do his or her part to benefit from the system; Little Free Libraries epitomize and stimulate a give-andtake relationship (Kozak, 2017; "Little Free Library FAQs," n.d.; Schnapp \& Battles, 2014, pp. 106-107, 111-113). In this case, people begin to think about how others might engage with or benefit from their book contributions (Aldrich, 2015; Aldrich, 2014; Cottrell, 2018; Guarino, 2015). For example, the General Manager of the Duke of York made the following statement about the pub's Little Free Library: "we have always strived to build a sense of community, and the Little Free Library brings with it an added air of delightful academia that the close proximity to the University of Toronto blends beautifully with. It is a perfect touchstone for both the neighbourhood residents, businesses, students and faculty" (Jay Ashmore, personal communication, April 4, 2018). The steward of the Euclid Ave. Little Free Library shared a similar response: "Since I put it up thousands of people have been by and many people have commented that it changed our small block in the neighborhood...people tell me they have met new friends in front of the library" (Ryan Penn, personal communication, April 3, 2018). These Little Libraries, in other words, depend on human involvement and synergy.

\section{Little Free Library as Infrastructure Experience}

In Standards and Their Stories, Lampland and Star (2009) define infrastructure as "something that other things 'run on,' things that are substrate to events and movements" (p. 17). Little Free Libraries are installed within already pre-existing neighbourhoods, and these two factors continuously impact each other (Lampland \& Star, 2009, pp. 11, 13, 17-18; Star, 1999, p. 381). Because infrastructure is "a fundamentally relational concept" (Star, 1999, p. 380), users may understand or experience Little Free Libraries in distinct ways. At first glance, the structure's purpose may be unclear-and so, it becomes "a target object to be learned about" (Star, 1999, p. 381). For example, due to confusion, a man in Minneapolis was collecting and attempting to sell the books of one Little Free Library (Megan, "Who Would Vandalize a Little Free Library?", 2016). Owners or stewards of Little Free Libraries, on the other hand, are very familiar with the functionality and organization of such a concept (Star, 1999, p. 380; Kozak, 2017; Webster, Gollner, \& Nathan, 2015).

Just as any other infrastructure, Little Libraries have established standards, or a particular set of instructions/guidelines for installation (Edwards et al., 2013, pp. 8-10; Star, 1999, pp. 381382; "Start Your Own Little Free Library," n.d.; Mattern, 2012). For one, their "location should 
also have a lot of foot traffic and be highly visible to anyone nearby" "'Start Your Own Little Free Library," n.d.). In addition, it is key that the Library is registered online and inputted on the map; this ensures formal recognition (e.g. a charter number) and affiliation to the Little Free Library brand (Star, 1999, pp. 381-382; “Start Your Own Little Free Library," n.d.). As mentioned above, the three Little Libraries of my expedition were, indeed, registered and labelled by the organization. See Appendices A, D, and G for charter signs and numbers.

Attitudes and opinions toward Little Free Libraries are plentiful and diverse. Some praise the organization and movement as a whole for promoting literary, free of digital restraints. It also creates and strengthens relationships within neighbourhoods and allows for innovative freedom, such as by painting and building the structures (Aldrich, 2015; Aldrich, 2014; Cottrell, 2018; Guarino, 2015; Smith \& Foster, 2012). One writer for the Los Angeles Times even makes a strong (though debatable) claim that they are "an almost perfect expression of literary democracy: Take a book, return a book, reading not as commodity exchange but exchange of identity, of ideas" (Ulin, 2015).

On the flip side, Little Free Libraries as "knowledge infrastructures also face limits, create tensions, and raise concerns" (Edwards et al., 2013, p. 11). Others question who, besides professionally trained librarians, should run libraries, even of variant forms; librarians also feel uneasy, as Little Libraries could lead to a reduction in government funding (Mattern, 2012; Kozak, 2017). People have even voiced their worry, regarding the cost of the Little Free Library creation process. If one orders a pre-made library structure and post, the cost would easily amount to over $\$ 200.00$ (Cottrell, 2018; “Libraries," n.d.; Schmidt \& Hale, 2017, pp. 15, 18-21). This does not include the charter number - an extra charge of at least $\$ 39.00$ ("Charter Signs and Registration," 2018, Cottrell, 2018; see also Schmidt \& Hale, 2017, p. 15). An academic study reveals that the Little Free Library objectives between mass media (e.g. newspaper) and stewards are quite different: universal and vague versus neighbourhood-specific (Webster, Gollner, \& Nathan, 2015). The former describes a large-scale or global initiative for change (e.g. in literacy), while the latter focuses in on the small-scale needs and aims of neighbours (Webster, Gollner, \& Nathan, 2015).

Mass media has directed attention to select disagreements between neighbourhoods, in which municipalities then intervened (Friedersdorf, 2015; News Staff, 2017). In September 2017 , an elderly Toronto man was required to pay a ticket of just under $\$ 100.00$ if he failed to remove his Little Free Library (News Staff, 2017). It was revealed that a neighbour objected to the structure's presence and informed the City; nonetheless, the man's daughters expressed 
great irritation for the situation, and the ticket was eventually withdrawn (News Staff, 2017). Similar instances have been publicized in the United States, such as in Los Angeles, Kansas, and Louisiana (Friedersdorf, 2015; Kozak, 2017).

The Little Free Library as an infrastructure has the potential to "becom[e] visible when it breaks" (Star, 1999, p. 382). By this I mean that Little Libraries can work quite successfully, until (1) the structure has been damaged (and therefore interrupted), ${ }^{3}$ or (2) people expose its flaws (Star, 1999, p. 382; Edwards et al., 2013, pp. 6-8, 14-15). The latter factor, in particular, requires further reflection and deconstruction. Here, the central issue is the "[r]each of scope" (Star, 1999, p. 381) of Little Free Libraries. Marianne Snow first questioned, crucially, "Where are LFLs typically located?" (Snow, 2015, p. 31). This leads into Schmidt and Hale's condemnation of the Little Libraries, as the pair argue that these structures seem to spring-up in more upscale neighbourhoods, thus perpetuating (and not solving) the 'book desert' dilemma (2017, pp. 14, 28-30). Such a term-'book desert'-has been defined as "a geographic area with a lack of access to books" (Schmidt \& Hale, 2017, p. 21). The two authors (also librarians) warn of the Little Free Library's problematic branding and marketing ploys; the organization asks people to 'purchase literacy' and stresses the importance of numbers (e.g. in Little Library structures and profits) and dissemination (Schmidt \& Hale, 2017, pp. 15, 18-19). In other words, Schmidt and Hale have marked Little Free Library as a "corporatization of a grassroots phenomenon" (Schmidt \& Hale, 2017, p. 18).

Furthermore, Schmidt and Hale (2017) articulate that the Little Free Library stands as a physical reminder (to both stewards and neighbours) of good deeds, as it seems to be predominantly for a 'showy' ego-boost (pp. 24-26). Some stewards have even revealed that they do not wish to engage with the users of their Little Library, which seems to be completely counter-productive (Schmidt \& Hale, 2017, p. 25). It is also worth noting, via Schmidt and Hale's research, the evident racial divide: Little Libraries reside in, largely, the white neighbourhoods of Toronto (2017, pp. 32-33). A Little Free Library program called Kids, Community \& Cops is also quite unsettling to the two authors; idealistic 'bonding' scenes of cops and youth (the latter, often minorities) distract from the tense reality these two groups share (Schmidt \& Hale, 2017, pp. 33$35)$.

In response to Schmidt and Hale's passionate commentary, an article in Library Journal wittingly rebuttals some of their arguments, worth briefly noting (Annoyed Librarian, 2017). For one, the author, simply named 'Annoyed Librarian', discloses that “[n]o libraries are free. 
Somebody has to pay for them" (2017). In addition, there are limitations to Schmidt and Hale's selection of merely two cities (Calgary and Toronto) in Canada, so as to make broader claims and accusations. The author even notes that librarians can be just as self-righteous about their duties as Little Free Library stewards (Annoyed Librarian, 2017).

I decided to conduct my own brief investigation of Toronto's Little Free Libraries, with Schmidt and Hale's piece in mind. I first visited Toronto Life, an online platform (blog) that provides a ranked list of neighbourhoods within the city ("The Ultimate Toronto Neighbourhood Rankings," n.d.). Here, I selected Toronto’s five least desirable neighbourhoods (e.g. low employment, high crime, low housing, and so on): Rustic (\#136), Etobicoke West Mall (\#137), Westminster-Branson (\#138), Parkwoods (\#139), and West Hill (\#140) (“Toronto Neighbourhood Rankings," n.d.). ${ }^{4}$ Following this, I accessed the Little Free Library map. After locating each of the neighbourhoods listed above, I realized that all five did not feature a Little Free Library ("Little Free Library Map," n.d.). I then looked into the three Little Free Libraries of my earlier expedition, in the Annex and Koreatown. The Annex was ranked within the top thirty neighbourhoods, at \#24 (“Toronto Neighbourhood Rankings," n.d.). Koreatown, within the Palmerston-Little Italy area, was placed at \#12 (“Toronto Neighbourhood Rankings," n.d.). Moreover, with further research, I discovered that of Koreatown's residents, almost half have obtained a university education, and just under $60 \%$ have annual incomes of roughly between $\$ 50,000$ and $\$ 150,000$ (Yu, n.d.). This investigation does show that we should conduct further research on the locations of Little Free Libraries and hold on to some skepticism-but should not conclude with generalizing accusations.

\section{A Little Free Library Future}

This essay has surveyed Little Free Libraries through the two lenses of library-variant and infrastructural experience. For the former, I applied Schnapp and Battles's The Library Beyond the Book (2014) library dimensions-connection, storage, activation, architectonics. This allowed for the marking of paths (either continuity or divergence) with traditional libraries and Little Free Libraries. For the latter, a fruitful and crucial discussion on the benefits and drawbacks maintains the concept's contentious nature (Aldrich, 2015; Aldrich, 2014; Annoyed Librarian, 2017; Schmidt \& Hale, 2017). Future research could deconstruct a larger sampling of Little Free Libraries, within the City of Toronto. It may also be insightful to compare how a few cities outside Canada or the US engage with these miniature libraries and where they are placed. With

$4 \quad$ This information has been updated since I first wrote this paper. Even still, the current (2019) five least desirable neighbourhoods do not have Little Free Libraries. 
BONDI | DOORS OPEN, DOORS CLOSED:TORONTO'S LITTLE FREE LIBRARIES

Toronto-specific action in mind, it would be valuable to work toward constructing Little Free Libraries in underprivileged, yet deserving, neighbourhoods. At the same time, the residents should then be encouraged to take charge of the structures, to bring a sense of control within their neighbourhood. Such a project could include interviewing members of these communities and reflecting on how they took part in the implementation of a Little Free Library. Shaw and Graham (2017), in light of Henri Lefebvre, make reference to "a 'right to the city'... [where] the great potential of urban life should be open to everyone" (p. 5). With this in mind, we can look to an improved, and thus promising, future for Little Free Libraries.

\section{References}

About Little Free Library. (n.d.). Retrieved from https://littlefreelibrary.org/about/.

Aldrich, M. (2015, April 15). 5 Reasons To Love Little Free Libraries. Huffington Post. Retrieved from https://www.huffingtonpost.com/margret-aldrich/reasons-to-love-littlefree-libraries_b_7066164.html.

Aldrich, M. (2014, July 27). The Low-Tech Appeal of Little Free Libraries. The Atlantic. Retrieved from https://www.theatlantic.com/education/archive/2014/07/the-low-techappeal-of-little-free-libraries/375101/.

Annoyed Librarian. (2017, May 8). Little Free Libraries are Bad Because We Don't Like Them. Library Journal. Retrieved from http://lj.libraryjournal.com/blogs/annoyedlibrarian/ 2017/05/08/little-free-libraries-are-bad-because-we-dont-like-them/.

Charter Signs and Registration. (n.d.). Retrieved from https://littlefreelibrary.myshopify.com/ collections/charter-signs.

Cottrell, M. (2018, January 2). The Question of Little Free Libraries. American Libraries Magazine. Retrieved from https://americanlibrariesmagazine.org/2018/01/02/questionlittle-free-libraries.

Edwards, P. N., Jackson, S. J., Chalmers, M. K., Bowker, G. C., Borgman, C. L., Ribes, D., Burton, M., \& Calvert, S. (2013). Knowledge Infrastructures: Intellectual Frameworks and Research Challenges. Ann Arbor, MI: Deep Blue. Retrieved from 
http://hdl.handle.net/2027.42/97552.

Friedersdorf, C. (2015, February 20). The Danger of Being Neighborly Without a Permit. The Atlantic. Retrieved from https://www.theatlantic.com/national/archive/2015/02/little-freelibrary-crackdown/385531/.

Guarino, M. (2015, April 9). Little Free Libraries Aim to Grow beyond Neighborhood Curiosity. Chicago Tribute. http://www.chicagotribune.com/lifestyles/books/ct-prj-little-freelibraries-20150409-story.html.

Homepage. (n.d.). Retrieved from https://ittlefreelibrary.org/.

Kozak, N. I. (2017). Building Community, Breaking Barriers: Little Free Libraries and Local Action in the United States. M/C Journal, 20(2). Retrieved from http://journal.mediaculture.org.au/index.php/mcjournal/article/view/1220.

Lampland, M. \& Star, S. L. (2009). Reckoning with Standards. In M. Lampland \& S. L. Star (Eds.), Standards and Their Stories: How Quantifying, Classifying, and Formalizing Practices Shape Everyday Life (pp. 3-33). Ithaca, NY: Cornell University Press.

Libraries. (n.d.). Retrieved from https://littlefreelibrary.myshopify.com/collections/little-freelibraries.

Little Free Library FAQs. (n.d.). Retrieved from https://ittlefreelibrary.org/faqs/.

Little Free Library World Map. (n.d.). Retrieved from https://ittlefreelibrary.org/ourmap/.

Mattern, S. (2012, May 22). Marginalia: Little Libraries in the Urban Margins. Places Journal. Retrieved from https://doi.org/10.22269/120522.

Megan, "Who Would Vandalize a Little Free Library?" (2016, September 20). Retrieved from https://littlefreelibrary.org/who-would-vandalize-a-little-free-library/.

News Staff. (2017, September 28). Big Win for GTA's Little Free Libraries. CityNews. Retrieved from http://toronto.citynews.ca/2017/09/28/big-win-for-gtas-little-freelibraries/. 
Schmidt, J. \& Hale, J. (2017). Little Free Libraries ${ }^{\oplus}$ : Interrogating the Impact of the Branded Book Exchange. Journal of Radical Librarianship, 3, 14-41. Retrieved from https://tspace.library.utoronto.ca/bitstream/1807/78805/1/17-1-93-1-10-20170418.pdf.

Schnapp, J. T., \& Battles, M. (2014). The Library Beyond the Book. MetaLABprojects. Cambridge, MA: Harvard University Press.

Shaw, J. \& Graham M. (2017). An Informational Right to the City? In Our Digital Rights to the City (pp. 4-5). Meatspace Press. Retrieved from https://meatspacepress.org/our-digitalrights-to-the-city/.

Smith, R. C., and Foster, M. (2012, June 21). How the Little Free Library Is Reinventing the Library. Huffington Post. https://www.huffingtonpost.com/russell-c-smith/little-freelibrary_b_1610026.html.

Snow, M. (2015). Little Free Libraries: A Call for Research into the Tiny Book Depositories. Children \& Libraries: The Journal Of The Association For Library Service To Children, 13(4), 30-32. Retrieved from https://journals.ala.org/index.php/cal/ article/view/5845/7357.

Star, S. L. (1999). The Ethnography of Infrastructure. American Behavioral Scientist, 43(3), 377 391. doi: 10.1177/00027649921955326.

Start Your Own Little Free Library. (n.d.). Retrieved from https://littlefreelibrary.org/start/.

The History of Little Free Library. (n.d.). Retrieved from https://ittlefreelibrary.org/ourhistory/.

The Ultimate Toronto Neighbourhood Rankings. (n.d.). Toronto Life. Retrieved from https://torontolife.com/neighbourhood-rankings/.

Ulin, D. L. (2015, April 15). Literary Democracy in Action: 'The Little Free Library Book.' Los Angeles Times. http://www.latimes.com/books/jacketcopy/la-et-jc-literarydemocracy-in-action-the-little-free-library-book-20150415-story.html.

Webster, T., Gollner, K. \&, and Nathan, L. (2015). Neighbourhood Book Exchanges: Localising Information Practices. Information Research, 20(9). Retrieved from 
http://www.informationr.net/ir/20-3/paper684.html.

Yu, Andrea. (n.d.). Koreatown. NextHome. Retrieved from https://nexthome.ca/ neighbourhoods/toronto-koreatown/30172/.

\section{Appendices}

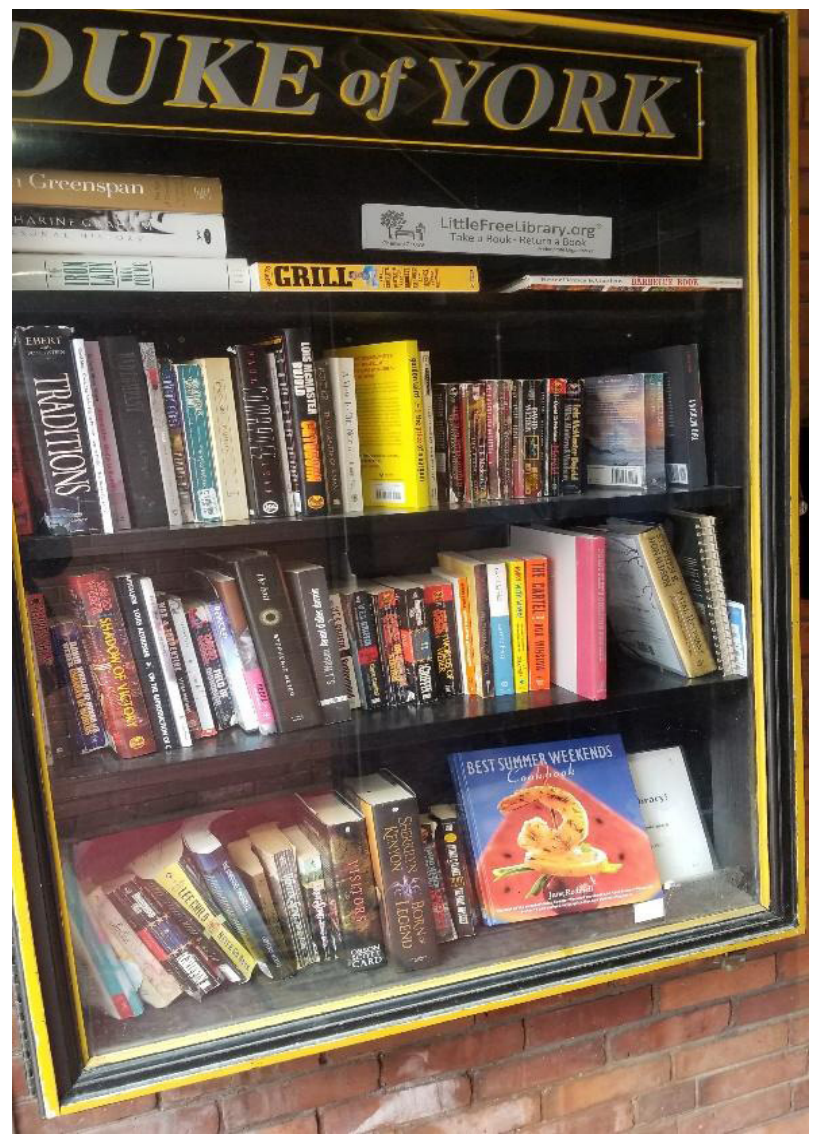

Appendix A: The Duke of York Little Free Library, April 4, 2018. (Pictured by Christina Bondi) 


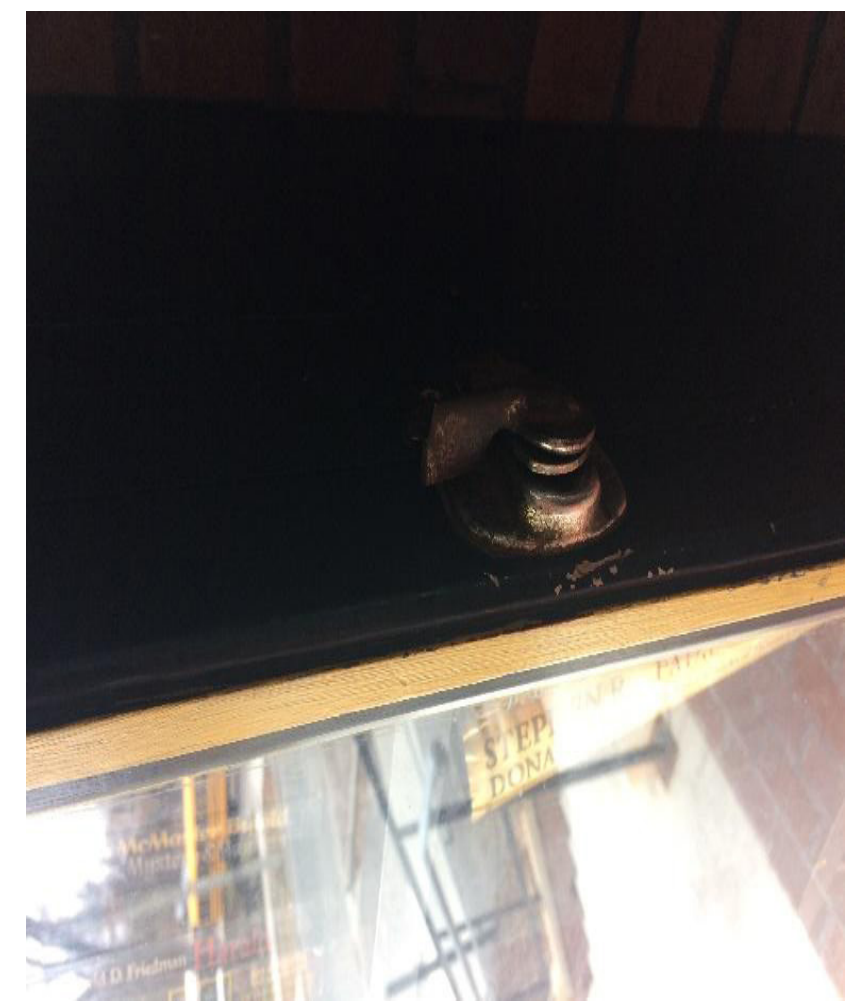

Appendix B: The Duke of York Little Library Latch, April 4, 2018. (Pictured by Christina Bondi)

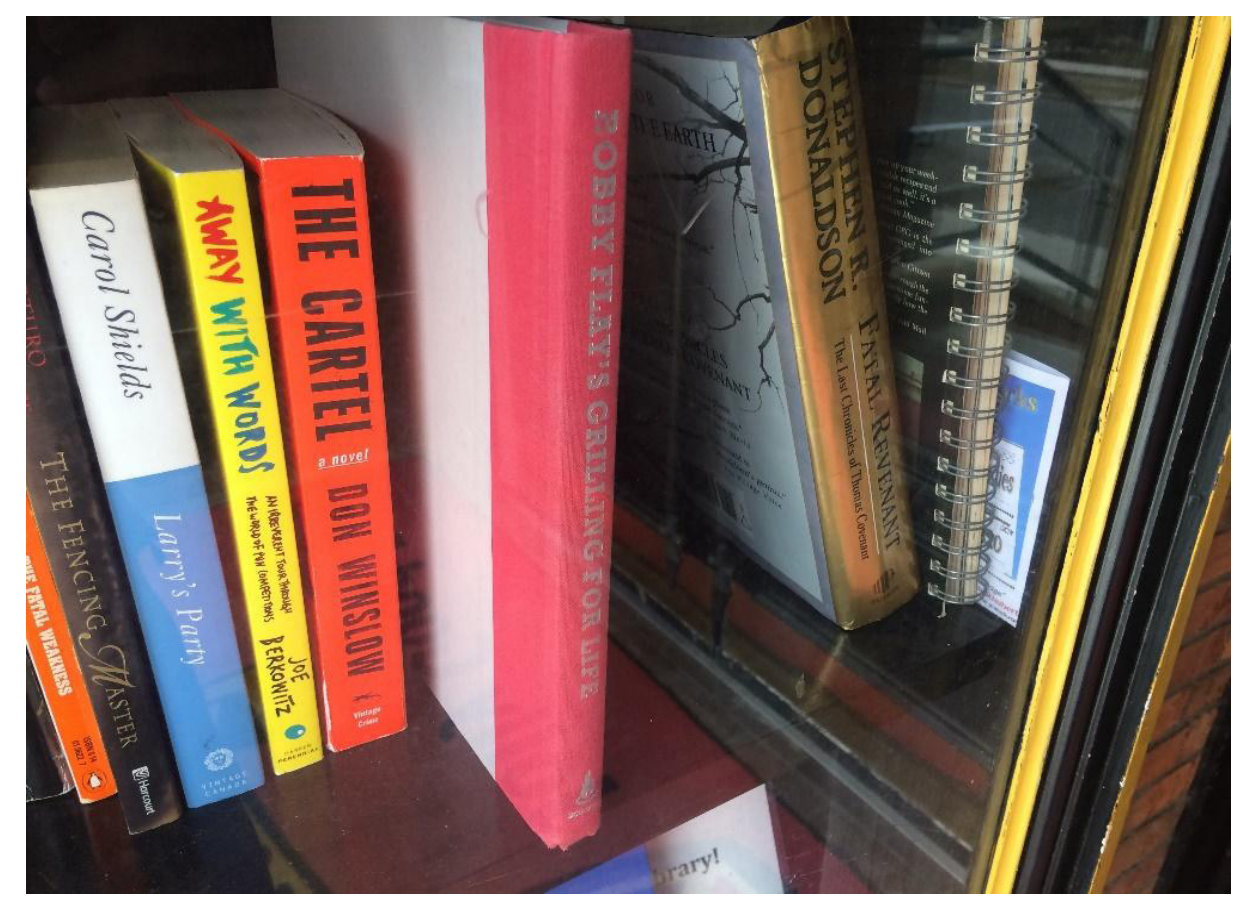

Appendix C: The Duke of York Little Free Library Book Selection, April 4, 2018. (Pictured by Christina Bondi) 


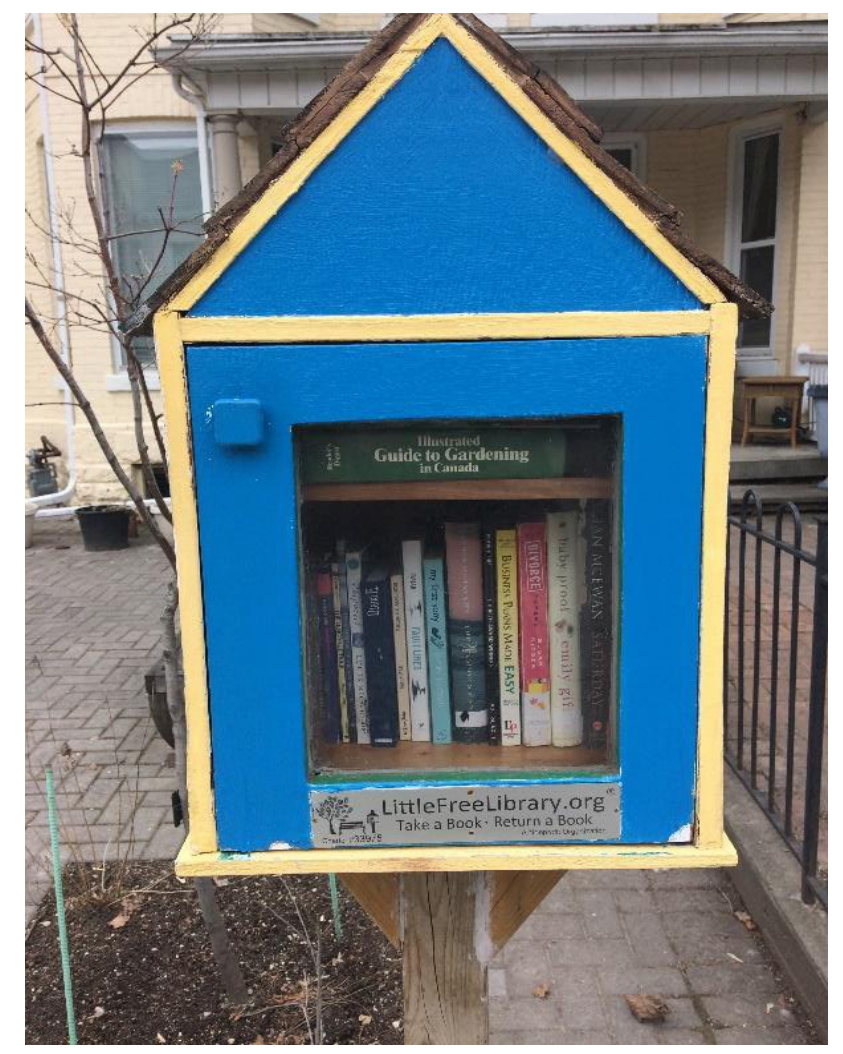

Appendix D: Brunswick Ave. Little Free Library, April 3, 2018. (Pictured by Christina Bondi)
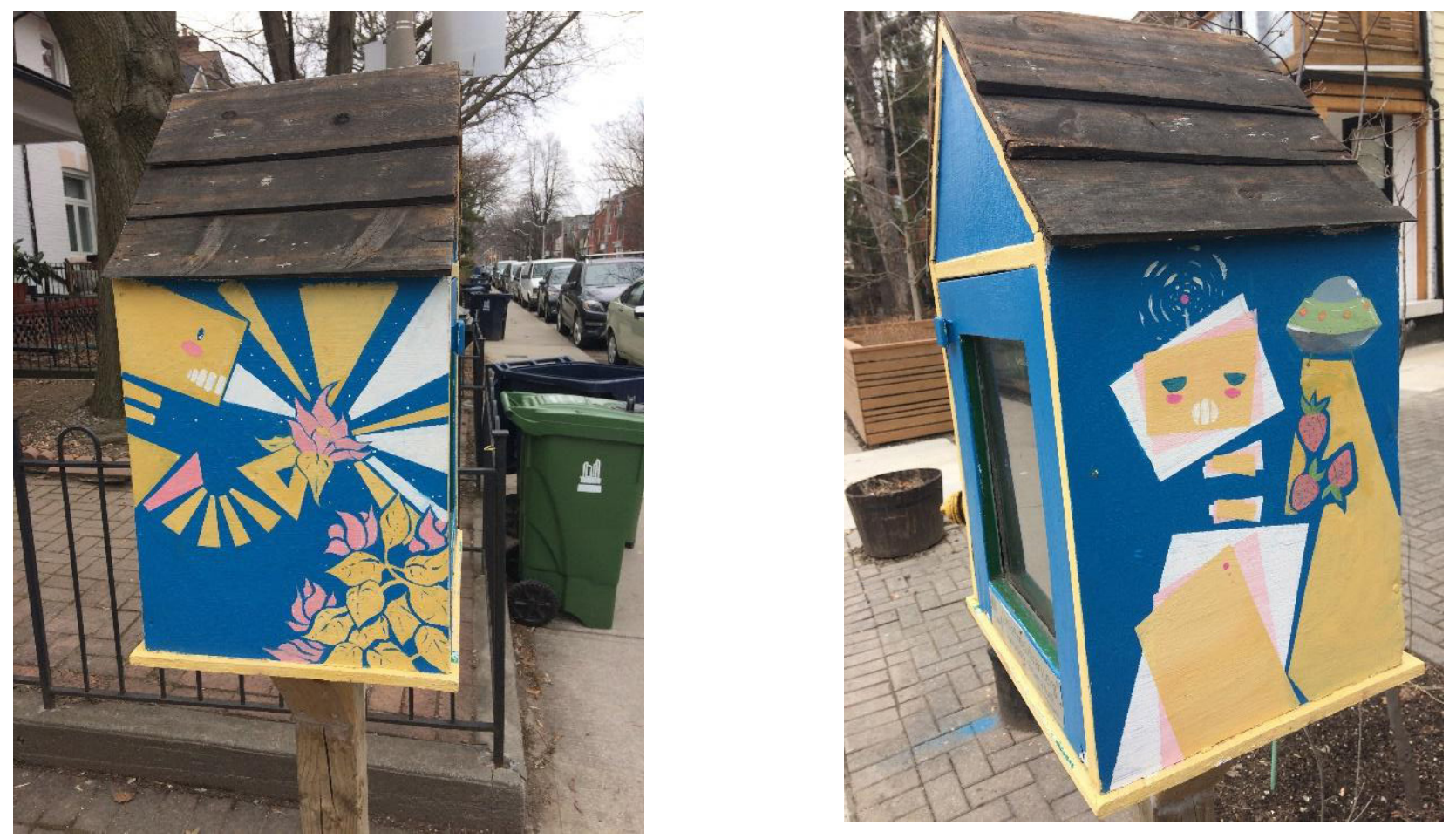

Appendix E: Brunswick Ave. Little Free Library Imagery, April 3, 2018. (Pictured by Christina Bondi) 


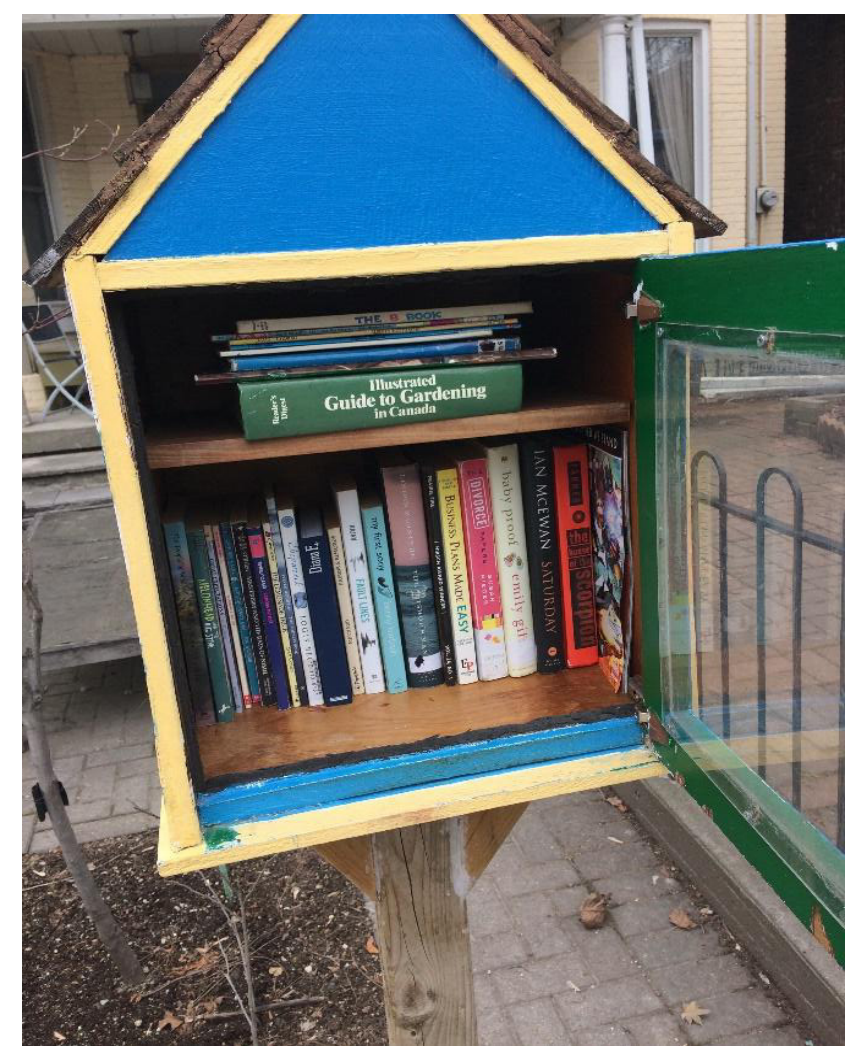

Appendix F: Brunswick Ave. Little Free Library Book Selection, April 3, 2018. (Pictured by Christina Bondi)

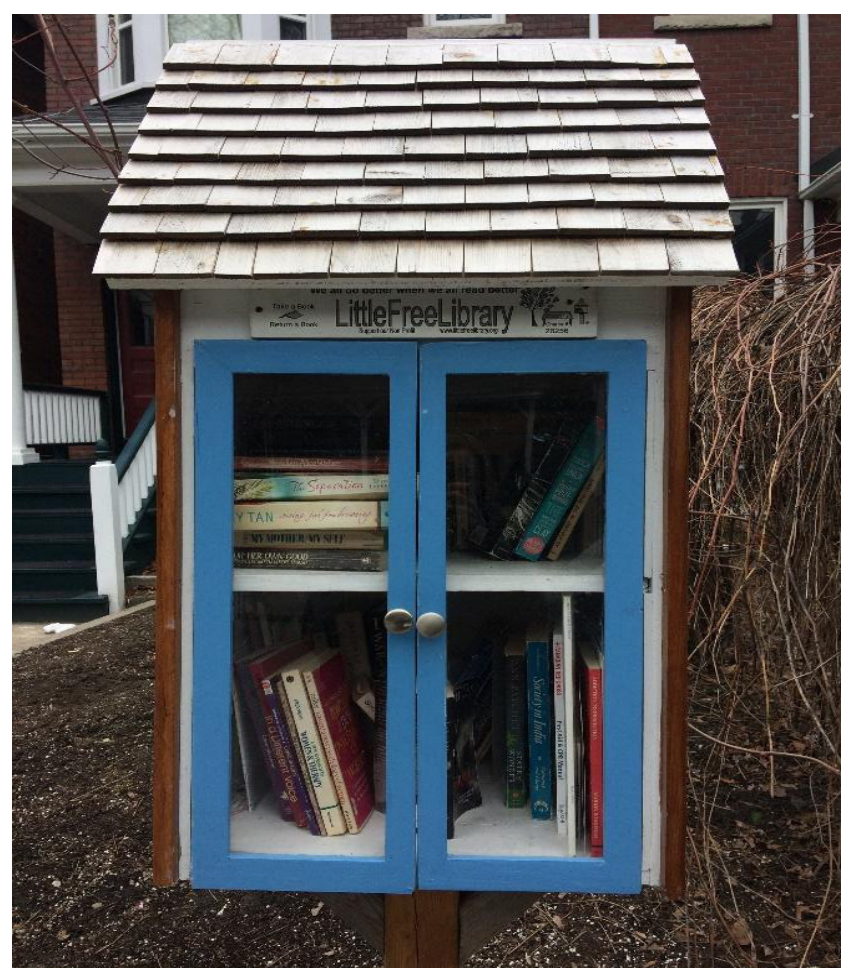

Appendix G: Euclid Ave. Little Free Library, April 3, 2018. (Pictured by Christina Bondi) 


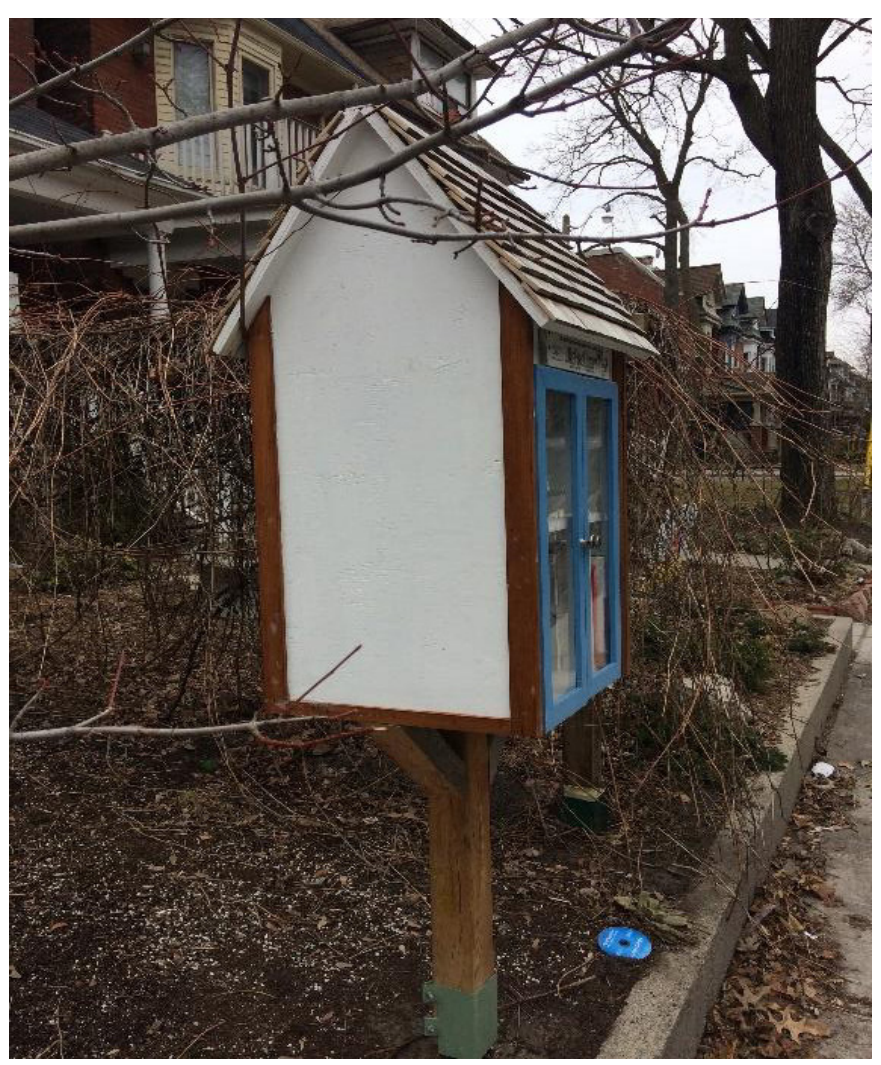

Appendix H: Euclid Ave. Little Library Side-Profile, April 3, 2018. (Pictured by Christina Bondi)

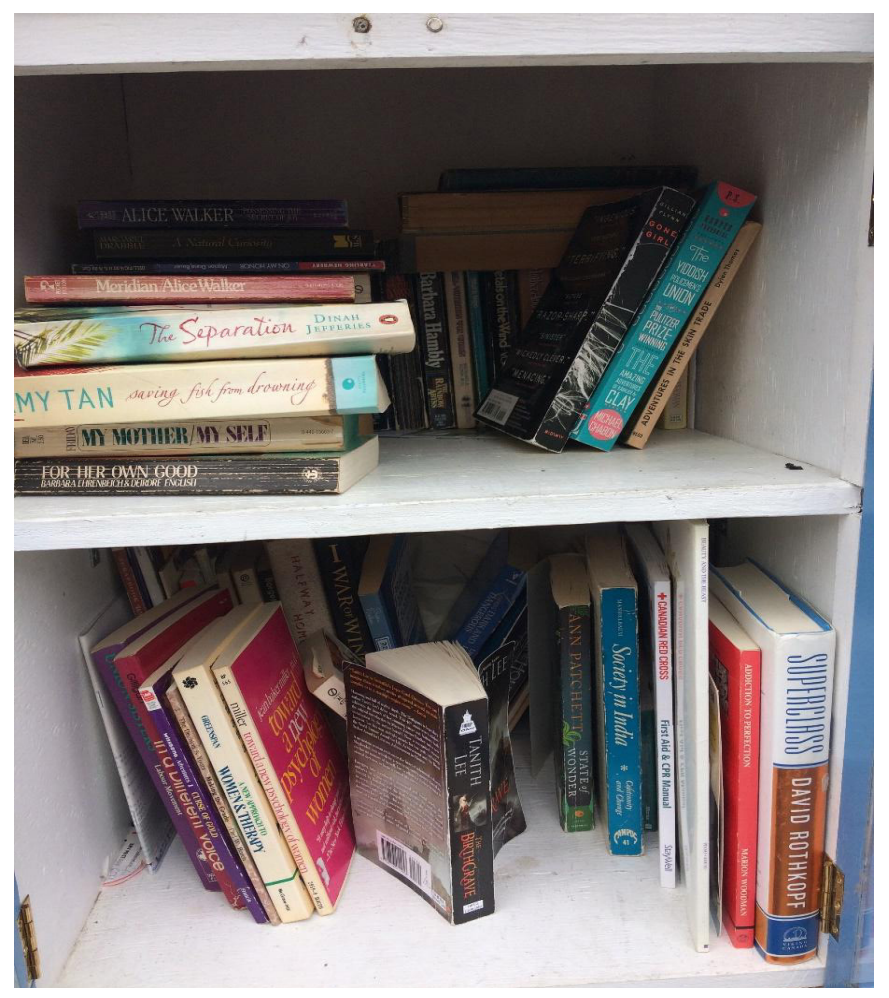

Appendix I: Euclid Ave. Little Library Book Selection, April 3, 2018. (Pictured by Christina Bondi) 